\title{
Analysis of Students Mathematical Reasoning Abilities on Number Topics
}

\section{Ishaq Nuriadin ${ }^{1}$, Lia Quratul 'Aini', Trisna Roy Pradipta1, Susilo²}

${ }^{1}$ Mathematic Education, Universitas Muhammadiyah Prof. Dr. Hamka, Indonesia

${ }^{2}$ Biologi Education, Universitas Muhammadiyah Prof. Dr. Hamka, Indonesia

*Email: ishaq_nuriadin@uhamka.ac.id

\section{ABSTRACT}

Mathematical reasoning skills are critical for students to solve math problems. The research objective was to determine the reasoning ability of junior high school students in solving number problems. This research is a qualitative descriptive study with case studies. The research subjects were 27 students consisting of 14 female students and 13 male students. A total of 10 questions were tested containing five multiple-choice questions, and five description questions. From the results of data analysis, $3 \%$ of students had high reasoning abilities, $43 \%$ of students had moderate reasoning abilities, $30 \%$ of students had low reasoning abilities, $13 \%$ of students had meagre reasoning abilities.

Keywords:

mathematical reasoning, numbers, TIMSS

Article Received: 18 October 2020, Revised: 3 November 2020, Accepted: 24 December 2020

\section{PENDAHULUAN}

The field of mathematics is often used as material for competency testing to continue education at a certain level. Mathematics is also used as a benchmark for selecting employees in a company (Krzemien et al., 2017). In education, mathematics has been included in the curriculum at all levels of education from kindergarten to college (Stout, 2019). In addition, the intensity of the lesson hours for mathematics is also more than for other subjects. This means that mathematics is essential for the life of all ages.

The existence of mathematics is caused by the human mind related to ideas or reason which is divided into four fields, namely algebra, arithmetic, analysis and geometry. (Ayan \& Isiksal-Bostan, 2019). Thus, actually from an early age, someone has been trained to reason by studying mathematics. The main characteristic of mathematics is the method of reasoning (Jonsson et al., 2016). This peculiarity is what makes reasoning an inseparable part of mathematics.

However, the students' ability in reasoning type questions is still very minimal. The achievement of students in Indonesia in the 2011 TIMSS (Trends in International Mathematics and Science Study) at the junior high school level in the cognitive dimension, namely knowing (knowledge) is 37\%, applying is $23 \%$ and reasoning is $17 \%$ (Saal et al., 2019). The three cognitive dimensions can be seen that reasoning is the lowest. The reasoning is a logical thinking process in concluding the form of knowledge. The result of this reasoning process will give us the knowledge to solve problems. The criteria for the truth of each individual are, of course, different, this is because accurate perceptions differ according to their knowledge. Table 1 shows the mathematics achievement of students in Indonesia obtained from the TIMSS infographic data in 2015 (Mullis et al., 2016).

Table 1. Mathematical achievement of students in Indonesia

\begin{tabular}{lc}
\hline \multicolumn{1}{c}{ Achievement } & Per cent of Students \\
\hline Students Confident in Mathematics & 23 \\
Students Like Learning Mathematics & 66 \\
Students' Views on Engaging Teaching in & 88 \\
Mathematics Lessons &
\end{tabular}


Computer Activities During Mathematics Lessons

6

Percentages of Students Taught the TIMSS Mathematics Topics 74

Average Percent Correct in the Mathematics Content and

Cognitive Domains

Teacher Participation in Professional Development in Mathematics

Teachers Majored in Education and Mathematics
The data shows that students who think mathematically are reasonable $(74 \%)$. Students in Indonesia tend to have good mathematical reasoning skills. Students with high mathematical abilities can estimate the problem-solving process and analyze mathematical situations appropriately, can formulate valid arguments, and be able to draw logical conclusions (Nurhayati, 2013). Meanwhile, students with mathematical abilities are estimating the completion process correctly but not in detail. Students with low math abilities are less able to analyze mathematical situations and compile valid arguments with less systematic settlement steps and are unable to draw logical conclusions.

This study used TIMSS model questions to measure students' mathematical reasoning abilities. The material to be discussed in this study numbers consisting of whole numbers and fractions. These questions have different dimensions of cognitive assessment, one of which is reasoning. In the cognitive domain of reasoning, multiple-choice questions and descriptions include the ability to analyze, generalize, integrate, justify, and solve non-routine problems. (Mullis et al., 2016). In addition, the TIMSS model questions not only use formulas but also require students to use their reasoning skills in the process of solving them.

The research objective was to determine the reasoning ability of junior high school students in solving number problems. The reasoning is one of the crucial aspects needed in mathematics, and the topic discussed was the numbers to be measured using questions from TIMSS.

\section{Method}

This research is a qualitative descriptive study with a case study which aims to describe students' mathematical reasoning abilities in solving number problems. A total of 27 students from junior high schools were involved to fill out the research instruments. The instrument used in the study was a test of reasoning and observation abilities. The results of the ability test were obtained based on the students' test scores. Types of data in the form of learning outcomes are then categorized qualitatively based on categorization techniques according to the methods of grading in Summative Evaluation from Bloom, Madaus \& Hastings (Gerson, 2003):

Table 2. Categories of Learning Outcomes

\begin{tabular}{|c|c|}
\hline The value of learning outcomes & Category \\
\hline $90 \leq \mathrm{x}$ & Very high \\
\hline $75 \leq \mathrm{x}<90$ & High \\
\hline $60 \leq \mathrm{x}<75$ & Moderate \\
\hline $40 \leq \mathrm{x}<60$ & Low \\
\hline $\mathrm{x}<40$ & Very low \\
\hline
\end{tabular}

The instrument of reasoning ability is in the form of test questions on number material taken from TIMSS questions in 2003, 2007, 2011 and 2015. The instrument contains ten items with 5 multiple choice questions and five essay questions, each of which if answered correctly, is given 10 points. The results of 
this test are used to determine students' reasoning abilities in solving number problems. TIMSS questions are used only on the content of the domain number (numbers). The content of this number domain contains three topics that are presented, namely, whole numbers, fractions, decimals, and whole numbers, as well as comparisons and percentages.

The results of the study were analyzed using indicators that were concluded from the TIMSS 2015 mathematics Framework, which is used to determine the reasoning ability of the subjects in table

Table 3. Indicators of reasoning ability according to TIMSS 2015

\begin{tabular}{|c|c|}
\hline Indicator & Reasoning Ability \\
\hline Analyze & $\begin{array}{l}\text { Determine, describe, or use relationships among numbers, } \\
\text { expressions, quantities, and shapes. }\end{array}$ \\
\hline Integrate/Synthesize & $\begin{array}{l}\text { Link different elements of knowledge, related representations, and } \\
\text { procedures to solve problems. }\end{array}$ \\
\hline Evaluate & Evaluate alternative problem-solving strategies and solutions. \\
\hline Draw Conclusions & id inferences on the basis of infor \\
\hline Generalize & $\begin{array}{l}\text { Make statements that represent relationships in more general and } \\
\text { more widely applicable terms. }\end{array}$ \\
\hline Justify & Provide mathematical arguments to support a strategy or solution. \\
\hline
\end{tabular}

The test questions following the reasoning indicators in this research are presented in table 4 .

Table 4. Mathematical Reasoning Test Questions

\begin{tabular}{|c|c|c|}
\hline Indicator & Item & Mathematical Reasoning \\
\hline Analyze & 4,5 & Determine, describe or use relationships between numbers \\
\hline Integrate/ Synthesize & 6 & Connect various elements of knowledge, related \\
\hline Evaluate & 2,3 & representations and procedures for solving problems \\
\hline Draw Conclusions & 9,10 & $\begin{array}{l}\text { Evaluating alternative strategies and problem-solving } \\
\text { solutions. }\end{array}$ \\
\hline Generalize & 7 & make valid conclusions based on information and evidence. \\
\hline Justify & 1,8 & make statements that represent the relationship more generally \\
\hline
\end{tabular}

\section{Finding and Discussion}

Based on the results of observations of researchers when the instrument was tested, the class conditions were quite conducive. Some students seemed confused by the questions given, occasionally someone whispered to their friends to ask the meaning of the questions, or someone asked the answers. Students feel the problem is different from what was taught. In contrast, the results of the distribution of the reasoning ability to answer student questions in each indicator measured through the students' correct answers can be seen in table 5 .

Table 5. Distribution of Student Answers on Each Indicator

\begin{tabular}{cccc}
\hline Indicator & Item & F & Percentage (\%) \\
\hline Analyze & 7 & 24 & 89 \\
Integrate/Synthesize & 6 & 15 & 56 \\
Evaluate & 2 & 8 & 30 \\
Draw Conclusions & 9 & 9 & 33
\end{tabular}




\begin{tabular}{clll} 
Generalize & 7 & 19 & 70 \\
Justify & 8 & 23 & 85 \\
\hline
\end{tabular}

Based on Table 5, most students can answer correctly on indicators to determine, describe or use relationships between numbers with a percentage of $89 \%$. Meanwhile, students' reasoning abilities on indicators connecting various elements of knowledge, related to representation, and procedures for solving problems were still not good with a percentage of $30 \%$. In addition, the achievement of students' mathematical reasoning abilities, according to the categories, is presented in Table 6.

Table 6. Categories of Students' Mathematical Reasoning Results

\begin{tabular}{ccc}
\hline Category & F & Percentage $(\%)$ \\
\hline Very high & 0 & 0 \\
High & 1 & 3 \\
Moderate & 13 & 43 \\
Low & 9 & 30 \\
Very low & 4 & 13
\end{tabular}

Based on these categories, most students have mathematical reasoning abilities in the moderate category, namely as much as $43 \%$. The analysis of students' reasoning abilities in each category is with indicators of determining, describing or using relationships between numbers.

\section{Answers to subjects with high reasoning abilities}

Analysis of the subject's answer shows that the subject correctly determines, describes or uses the relationship between numbers.

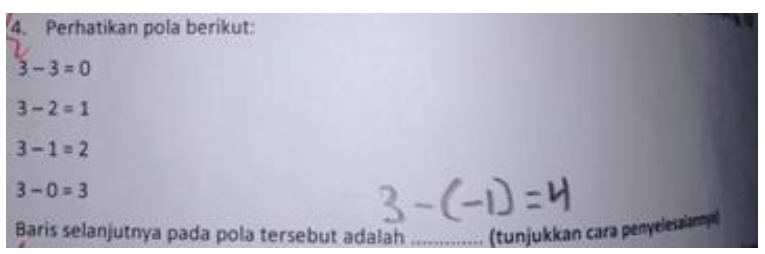

Figure 1. Answers to the subject with high abilities

From the results of students' answers to item no. 4 high-ability students are seen to understand the pattern formed from each sequence of similarities with the subtraction operation for number 3.By looking at the first line, three minus 3 , then in the second line, three minus 2, up to the fourth line, number 3 minus 0 . This means that between the first line and the next line, the number that is subtracted from the number 3 is getting smaller by the difference of 1 . Based on this understanding, the students succeeded in determining that in the fifth row, the number 3 was subtracted from the number $(-1)$. Likewise, the result of the reduction is 4 .

\section{Answers to subjects with moderate reasoning abilities}

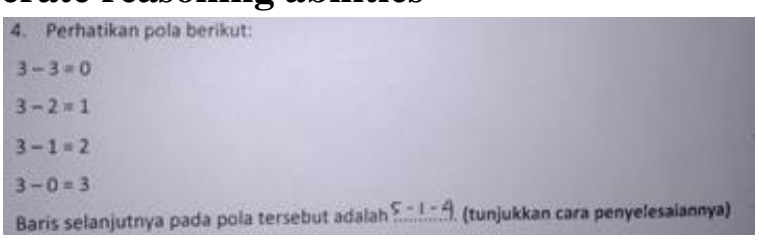

Figure 2. Answers to subjects with moderate ability 
From the results of students' answers to item no. 4 , there was an error writing the sign. Students intending to write "5-1 = 4" in the answer. Students only managed to see the pattern that was on the right side of each similarity. The pattern of the right side forms a sequence of $0,1,2,3$ so that the student manages to determine that the next number is 4 . However, the student fails to see the pattern that is on the left side of the similarity. Based on the answer on the right side, with his intuition, he wrote the subtraction for the left side which he thought was easy, namely "5-1".

\section{Answers to subjects with low reasoning abilities}

From the results of students' answers to item no. 4, students with low abilities appear to be able to see the pattern formed from the right side of each line of similarity but fail to see the pattern formed on the left side. Furthermore, it appears that students have not mastered the subtraction operation of integers. This is shown by writing 3-7 according to which the result is 4 .

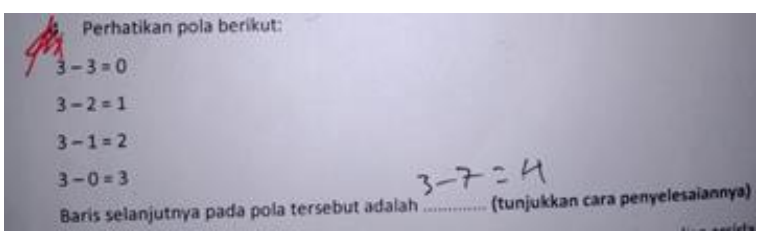

Figure 3. Answers to low proficiency subjects

Based on the test results, students' reasoning abilities are high, medium and low. Highly skilled students can analyze mathematical situations using patterns and relationships appropriately, and systematic work steps, can formulate valid arguments and be able to draw logical conclusions (Kan et al., 2019). Students with moderate abilities can analyze mathematical situations using patterns and relationships appropriately, and unsystematic steps, so they are less able to formulate valid arguments and are less able to draw logical conclusions (Alexander et al., 2016). Low-ability students can analyze mathematical situations using patterns and relationships appropriately, but the steps are less systematic, so they are less able to formulate valid arguments, and are less able to draw logical conclusions (Gürbüz \& Erdem, 2016).

Herutomo (2014) states that errors are caused by students representing and interpreting the information presented in questions in the form of story questions. An error is caused by ignorance of the concept of the subject because to understand the meaning of the questions that have been presented, and the subject must master the material and know the concepts related to the problem (Fyfe \& Brown, 2018). In addition,
Savitri (2014), concluded that most students only understand the concept. So that when faced with a new problem, they experience the confusion that leads to mistakes. The causes of errors in students with the Field Dependence (FD) cognitive style group are more dominated by incomplete student reasoning and students' inadequate ability to understand and remember the material they have received (Krzemien et al., 2017).

The errors experienced by students in solving story problems in the aspect of understanding the problem are errors in interpreting language and mathematical models (Kan et al., 2019). The causes of errors in the aspect of understanding language are students' low mathematical abilities and incomplete/wrong student reasoning.

\section{Conclusion}

Students who are highly capable of reasoning can analyze mathematical situations using patterns and relationships appropriately, and systematic work steps, can formulate valid arguments and be able to draw logical conclusions. Low ability students are less able to formulate valid arguments and less able to draw logical conclusions. Students' reasoning abilities can be improved by changing learning methods, such as providing 
particular practice questions that require reasoning so that students are accustomed and able to reason well.

\section{References}

[1] Alexander, P. A., Dumas, D., Grossnickle, E. M., List, A., \& Firetto, C. M. (2016). Measuring Relational Reasoning. Journal of Experimental Education, 84(1), 119-151. https://doi.org/10.1080/00220973.2014.9632 16

[2] Ayan, R., \& Isiksal-Bostan, M. (2019). Middle school students' proportional reasoning in real life contexts in the domain of geometry and measurement. International Journal of Mathematical Education in Science and Technology, 50(1), 65-81. https://doi.org/10.1080/0020739X.2018.146 8042

[3] Fyfe, E. R., \& Brown, S. A. (2018). Feedback influences children's reasoning about math equivalence: A meta-analytic review. Thinking and Reasoning, 24(2), 157-178.

https://doi.org/10.1080/13546783.2017.1359 208

[4] Gürbüz, R., \& Erdem, E. (2016). Relationship between mental computation and mathematical reasoningi. Cogent Education, $3(1), \quad 1-18$. https://doi.org/10.1080/2331186X.2016.121 2683

[5] Jonsson, B., Kulaksiz, Y. C., \& Lithner, J. (2016). Creative and algorithmic mathematical reasoning: effects of transferappropriate processing and effortful struggle. International Journal of Mathematical Education in Science and Technology, 47(8), 1206-1225. https://doi.org/10.1080/0020739X.2016.119
2232

[6] Kan, A., Bulut, O., \& Cormier, D. C. (2019). The Impact of Item Stem Format on the Dimensional Structure of Mathematics Assessments. Educational Assessment, 24(1), 13-32. https://doi.org/10.1080/10627197.2018.1545 569

[7] Krzemien, M., Jemel, B., \& Maillart, C. (2017). Analogical reasoning in children with specific language impairment: Evidence from a scene analogy task. Clinical Linguistics and Phonetics, 31(7-9), 573-588.

https://doi.org/10.1080/02699206.2017.1302 509

[8] Mullis, I. V. S., Martin, M. O., Foy, P., \& Hooper, M. (2016). IMSS 2015 International Results in Mathematics. Boston College, TIMSS \& PIRLS International Study Center.

[9] Saal, P. E., van Ryneveld, L., \& Graham, M. A. (2019). The relationship between using information and communication technology in education and the mathematics achievement of students. International Journal of Instruction, 12(3), 405-424. https://doi.org/10.29333/iji.2019.12325a

[10] Savitri, M. E. (2014). Analisis kesalahan siswa pada materi pecahan dalam bentuk aljabar ditinjau dari gaya kognitif siswa kelas VIII di SMP Negeri 2 Adimulya Kabupaten Kebumen tahun 2013/2014. Jurnal Elektronik Pembelajaran Matematika, 4.

[11] Stout, R. (2019). Practical reasoning and practical knowledge. Canadian Journal of Philosophy, 49(4), 564-579. https://doi.org/10.1080/00455091.2018.146 3839 